\title{
Impacts of Genetic Enhancement in Pearl Millet
}

\author{
M.C.S. BANTILAN AND U.K. DEB
}

This chapter documents the benefits from pearl millet genetic enhancement research conducted by the International Crops Research Institute for the Semi-Arid Tropics (ICRISAT) in partnership with national agricultural research systems (NARS). ICRISAT-NARS research efforts and the resultant impacts are summarized, recognizing that many improved pearl millet cultivars are the joint products of the partnership. Benefits from pearl millet improvement research are measured in terms of yield gain, reductions in production cost and increases in profitability. This study documents the record of pearl millet germplasm improvement in the form of open-pollinated varieties (OPVs) and hybrids released by national programmes. Data based on farm-level surveys and secondary sources are used to generate productivity and other impact measures. The results indicate that pearl millet farmers adopted improved varieties based on early maturity, yield and profitability gains. Early maturing pearl millet cultivars have proven particularly desirable in drought-prone regions where food security is a severe problem. Lastly, this chapter presents an example of South-South research spillover, where research products developed at ICRISAT found applicability and adaptability across India and sub-Saharan Africa. The results highlight the critical role that an international research institution such as ICRISAT has in enabling research spillovers across national and continental boundaries. 


\section{Introduction}

Pearl millet (Pennisetum glaucum) is a highly drought-tolerant cereal crop and an important food grain. It is generally grown as a rainfed crop on marginal lands with few inputs and little management. Pearl millet provides food for millions of people living in the arid and semi-arid regions of the Indian subcontinent and Africa. It is grown as a food crop in tropical Africa and India, with most production concentrated in Sahelian west Africa and northwestern India. These regions are characterized by high temperatures, short growing season, frequent drought, and sandy and infertile soils. In addition to its use for food, pearl millet has a high feed value for poultry and is a good source of energy and nitrogen in ruminant diets.

Accurate statistics on the area, production and productivity of pearl millet are not available, as pearl millet statistics are often grouped with other minor millets. According to Dendy (1995), pearl millet accounts for only $3.5 \%$ of world cereals area and about $1 \%$ of the total cereal production. However, it is an extremely important crop in the arid and semi-arid zones, where it is difficult to grow other crops. Harinarayana et al. (1999) reported that pearl millet is cultivated in over 30 countries of Asia and Africa on a total area of 24.2 million ha and production is around 16.3 million t. Of this, nearly half is in Asia, with India accounting for 10.4 million ha, or $43 \%$ of the total world area. ICRISAT and FAO (1996) provided information on total millet area, production and yield and mentioned the proportion of pearl millet production to total millet production for the period 1992-1994. For the present study, we have compiled information on total millet area, production and yield from FAO (1998) and reported annual averages for 1996-1998 (Table 10.1).

In India, this crop is grown in the drier areas of the central and western regions. Five states (Rajasthan, Maharashtra, Gujarat, Uttar Pradesh and Haryana) account for nearly $90 \%$ of the national pearl millet area. Western Africa accounts for nearly $45 \%$ of world pearl millet area. The crop is grown in 17 countries in this region, but five countries (Niger, Nigeria, Burkina Faso, Mali and Senegal) account for nearly $90 \%$ of the total cultivated area in the region.

Pearl millet grain yields are low, largely because of the harsh environments in which it is grown and also because farmers do not invest in purchased inputs. Yields range from over $1 \mathrm{t} \mathrm{ha}^{-1}$ in some countries to as little as $240 \mathrm{~kg} \mathrm{ha}^{-1}$ in Botswana and Namibia (Table 10.1).

Generally, yield growth has been poor, and production increases have come largely through area expansion rather than higher productivity. However, pearl millet area in India is steadily decreasing (Kelly and Parthasarathy Rao, 1993). Since 1960-1965 about 0.9 million ha have gone out of pearl millet cultivation, particularly in Gujarat, Uttar Pradesh, Haryana, Tamil Nadu, Andhra Pradesh and Punjab. 
Table 10.1. Area, production and productivity of millet in Asia and Africa. 1996-1998.

\begin{tabular}{|c|c|c|c|c|c|}
\hline \multicolumn{2}{|c|}{ Country } & \multirow[t]{2}{*}{$\begin{array}{c}\text { Area } \\
\left(10^{3} \text { ha }\right)\end{array}$} & \multirow[t]{2}{*}{$\begin{array}{l}\text { Production } \\
\qquad\left(10^{3} \mathrm{t}\right)\end{array}$} & \multirow[t]{2}{*}{$\begin{array}{c}\text { Grain } \\
\text { yield } \\
\left(\mathrm{kg} \mathrm{ha}^{-1}\right)\end{array}$} & \multirow[t]{2}{*}{$\begin{array}{l}\% \text { share of pearl } \\
\text { millet to total } \\
\text { millet production }\end{array}$} \\
\hline A. & Asia & & & & \\
\hline 1 & India & $13,433.3$ & 10.713 .0 & 797 & 58 \\
\hline 2 & Myanmar & 224.2 & 149.5 & 667 & 85 \\
\hline 3 & Pakistan & 407.6 & 189.4 & 466 & 97 \\
\hline 4 & Yemen & 97.7 & 59.6 & 604 & 100 \\
\hline Suk & total & $14,162.8$ & $11,111.5$ & 784 & \\
\hline \multicolumn{6}{|c|}{ B. Western Africa } \\
\hline 5 & Benin & 36.9 & 28.3 & 766 & 100 \\
\hline 6 & Burkina Faso & $1,203.1$ & 673.0 & 557 & 99 \\
\hline 7 & Cote d' Ivoire & 92.7 & 63.6 & 686 & 85 \\
\hline 8 & Cameroon & 70.0 & 70.9 & 1,013 & 100 \\
\hline 9 & Central African Republic & 11.3 & 11.3 & 1,000 & 87 \\
\hline 10 & Chad & 697.3 & 290.5 & 414 & 100 \\
\hline 11 & Gambia & 67.5 & 64.6 & 968 & 97 \\
\hline 12 & Ghana & 170.1 & 166.3 & 980 & 100 \\
\hline 13 & Guinea & 10.5 & 8.1 & 775 & 95 \\
\hline 14 & Guinea-Bissau & 29.6 & 26.4 & 890 & 100 \\
\hline 15 & Mali & $1,052.3$ & 747.7 & 725 & 95 \\
\hline 16 & Mauritania & 18.6 & 3.7 & 181 & 100 \\
\hline 17 & Niger & $5,200.0$ & $1,752.7$ & 337 & 100 \\
\hline 18 & Nigeria & 5.447 .3 & 5.836 .3 & 1,071 & 98 \\
\hline 19 & Senegal & 871.4 & 484.8 & 553 & 100 \\
\hline 20 & Sierra Leone & 24.0 & 19.6 & 818 & 100 \\
\hline 21 & Togo & 100.1 & 48.5 & 485 & 100 \\
\hline Sul & total & $15,102.7$ & $10,296.3$ & 682 & \\
\hline \multicolumn{6}{|c|}{ C. Southern and Eastern Africa ${ }^{b}$} \\
\hline 22 & Angola & 184.6 & 84.3 & 453 & 80 \\
\hline 23 & Botswana & 8.3 & 2.3 & 264 & 100 \\
\hline 24 & Malawi & 37.5 & 18.6 & 497 & 40 \\
\hline 25 & Mozambique & 92.8 & 46.4 & 499 & 80 \\
\hline 26 & Namibia & 268.8 & 66.2 & 240 & 100 \\
\hline 27 & Sudan & $2,465.8$ & 736.7 & 294 & 100 \\
\hline 28 & Tanzania & 311.2 & 287.3 & 894 & 70 \\
\hline 29 & Zambia & 79.0 & 59.4 & 751 & 40 \\
\hline 30 & Zimbabwe & 260.7 & 94.4 & 356 & 70 \\
\hline \multicolumn{2}{|c|}{ Subtotal } & 3.708 .7 & $1,395.6$ & 376 & \\
\hline \multicolumn{2}{|c|}{ Total $^{c}$} & $32,974.2$ & $22,803.4$ & 692 & \\
\hline
\end{tabular}

${ }^{\text {a }}$ Percentage share of pearl millet to total millet production is taken from ICRISAT/FAO (1996) and relates to 1992-94.

${ }^{b}$ Kenya $(1400 \mathrm{t})$ and Ethiopia (5000 t) are also reported to be producing pearl millet (Harinarayana et al., 1999).

'In addition, pearl millet is grown on limited areas in Australia, Korea and USA (estimated around 1 million ha) for forage (Harinarayana et al., 1999).

Source: FAO Statistical Data Base (1998). 


\section{Research Methodology}

This study draws on a three-pronged approach (Fig. 10.1) to track usage of pearl millet parental lines. First, ICRISAT records provided data on the distribution of elite materials, hybrid parents and released open-pollinated varieties (OPVs) from the ICRISAT breeding programme to NARS seed multiplication agencies (public or private). This analysis was carried out for the period 1986-1998. Second, questionnaires were sent to 160 companies dealing with sorghum and pearl millet seed. A total of 49 companies (of which 37 dealt with pearl millet) responded. They provided information on the nature, extent and importance of ICRISAT breeding materials in their breeding and seed production programmes. Third, on-farm surveys were carried out in India (1683 farmers), Mali (345 farmers), Namibia and Zimbabwe. Information was gathered on adoption of different pearl millet cultivars, farm and farmer characteristics, farmer preferences for specific traits in the improved cultivars, and constraints to the cultivation of improved varieties.

In India, a total of 1683 farmers from 154 villages in five states, namely Maharashtra (360 farmers), Rajasthan (331), Gujarat (419), Haryana (237) and Tamil Nadu (336) were selected. Improved pearl millet cultivars were categorized into five groups: ICRISAT cultivars,

Approach 1:

Data on distribution of breeder seed from ICRISAT

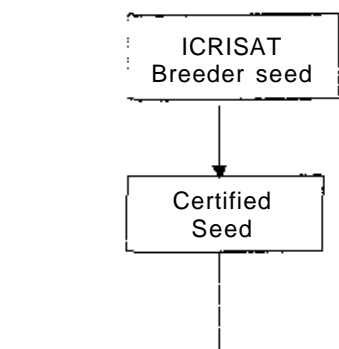

Approach 2:

Records and survey data from private and public seed companies
Approach 3:

Reconnaissance surveys

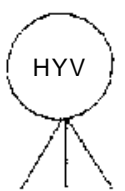

By variety
Public/private seed companies

- Production

- Market

- Carry over

- Distribution

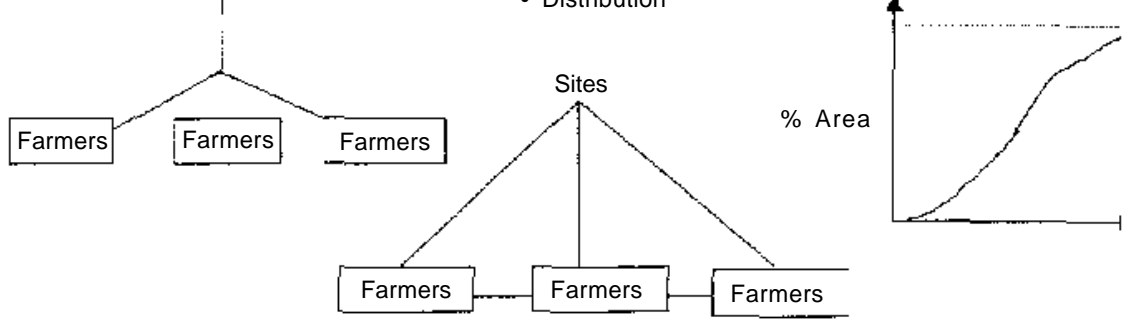

Fig. 10.1. Three approaches to track the adoption and impact of investments in pearl millet research at ICRISAT. 
NARS-Public sector cultivars with ICRISAT materials, Private sector cultivars with ICRISAT materials, NARS-Public sector cultivars without ICRISAT materials and Private sector cultivars without ICRISAT materials. Some farmers were not able to name the variety which they grew, but were sure it was an improved cultivar. In such cases we have mentioned the cultivar as unidentified.

\section{Human Resources Involved}

Human resources involved in pearl millet genetic enhancement research in Asia and Africa are reported in Table 10.2. At ICRISAT, about five millet breeders are located in Asia and Africa. Fifteen other scientists, including agronomists, crop physiologists, genetic resources specialists, entomologists, pathologists and social scientists are generating information for effective use by the breeders. In India, about 150 pearl millet scientists in the public and private sector are working on this crop. However, in African countries few scientists work on this crop. Many are devoted to more than one crop; often millet and sorghum are combined.

\section{The Research Process}

\section{Pre-breeding research}

Collection, characterization and maintenance of landraces are essential for crop improvement, and these activities have been a high priority at ICRISAT. As of December 1999, 21,392 pearl millet germplasm accessions from 50 countries conserved at ICRISAT. After collection and assembly, ICRISAT and its NARS partners conduct evaluation trials to identify the useful traits available in the assembled germplasm. This information has been disseminated to researchers worldwide through reports, journal papers and other fora. In response to requests from users, ICRISAT has distributed 94,818 pearl millet germplasm samples to 74 countries: $69 \%$ were distributed to Asia, $27 \%$ to Africa, and $4 \%$ to other continents (Genetic Resources Unit, ICRISAT, 1999, personal communication).

\section{ICRISAT's evolving focus}

Research at ICRISAT began in 1972 with greater emphasis on applied rather than basic research. The focus was on grain yield and downy mildew resistance and exploratory research on ergot, smut, and rust resistance and drought tolerance. Equal emphasis was given to the 
Table 10.2. Number of pearl millet scientists in different countries (1999 or latest year).

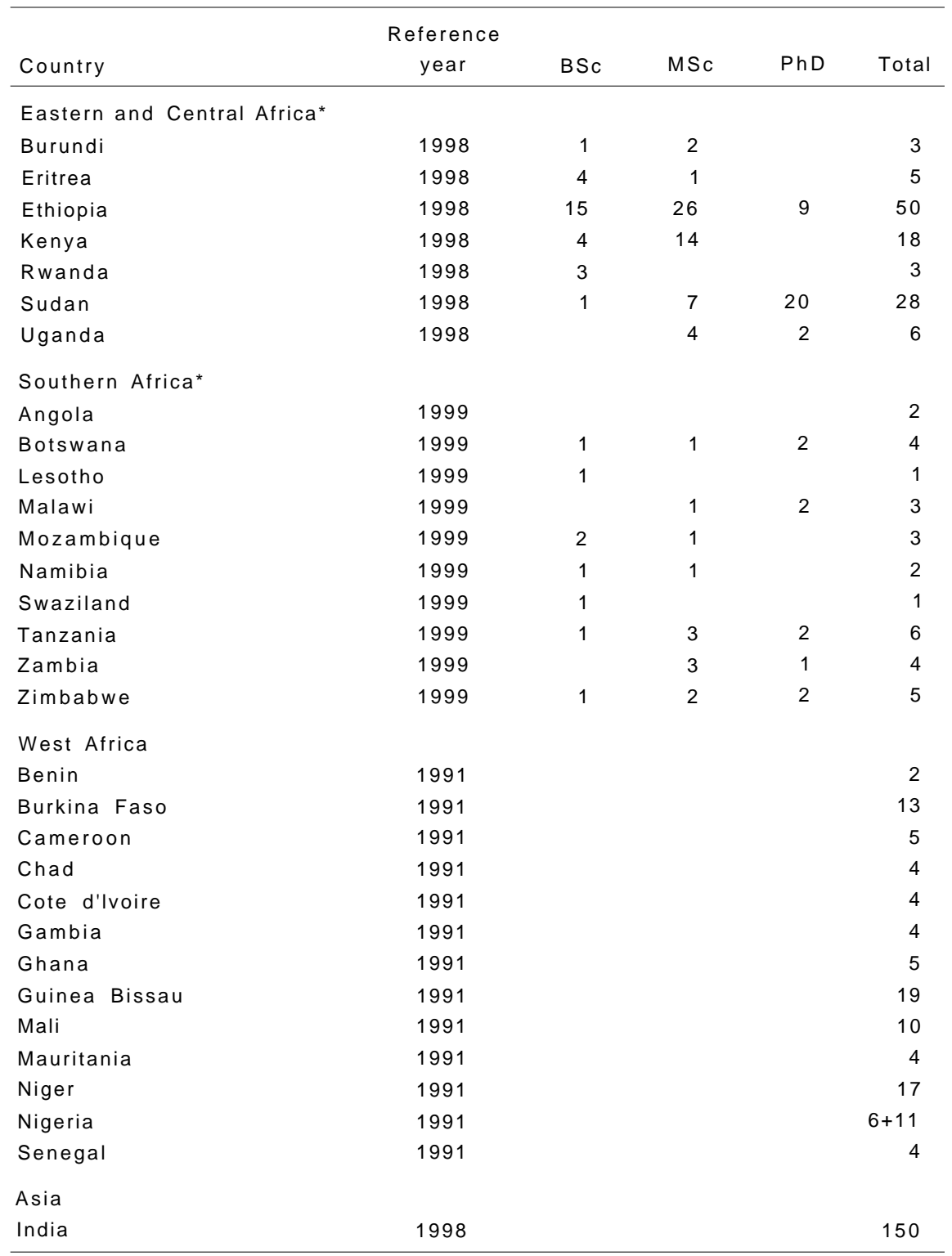

Note: *Scientists working in Eastern and Central Africa, and southern Africa are involved in both sorghum and millet research.

Source: For Asia and southern Africa, ICRISAT Impact Monitoring Survey, 1998-2000; For Eastern and Central Africa, Association for strengthening agricultural research in Eastern and Central Africa, ASARECA (1998):

For West Africa, Anand Kumar (1993). 
development of finished products (cultivars) and improved breeding materials/parental lines. Development of improved breeding and screening methodologies was an integral part of applied research (Rai and Hash, 1994).

In the 1970s, breeding of open-pollinated varieties (OPVs), rather than hybrids, was emphasized. This was because ICRISAT had a comparative advantage over NARS, in terms of conducting large-scale interpopulation improvement programmes across multiple locations. The Indian NARS had weak or no programmes in OPV breeding in the 1970s. Population breeding products (i.e. improved composites, openpollinated varieties, early-generation progenies) were perceived to have the additional advantage of strengthening NARS hybrid programmes by providing improved germplasm for deriving hybrid parents. Indian NARS had adequate capacities to develop male-sterile lines. Hence ICRISAT devoted itself to producing restorers, and took to male-sterile lines breeding at a formal project level in the late 1970 s.

Since the early 1980 s, there has been a considerable improvement in the research capability of NARS in pearl millet research, especially in the Indian subcontinent. This has led to a reordering of ICRISAT's priorities. There was a shift in emphasis towards strategic research followed by continued emphasis on grain yield and downy mildew resistance. Almost all efforts were directed towards the development of improved breeding materials/parental lines (except for a few experimental varieties developed in partnership with NARS). Special effort was made to further refine breeding and screening methodologies, including the application of biotechnology, and relatively greater emphasis than in the past on escaping drought through early maturity (Rai and Hash, 1994).

Breeding for resistance to biotic and abiotic stresses focused mainly on downy mildew resistance, There was very limited research on ergot, smut and rust diseases (Hash, 1997). In India, downy mildew has been the major constraint to production since the $1960 \mathrm{~s}$, shortly after hybrids were widely introduced. Since then it has been a major research focus by both ICRISAT and the national programme (Nene and Singh, 1976; Dave, 1987; Rai and Singh, 1987; Shetty, 1987; Singh et al., 1987, 1993). Hash (1997) reviewed the history of downy mildew research. From the published records and from the personal experience initially of D.J. Andrews and Hugh Doggett, it was clear that West African germplasm provided the best sources of genetic diversity for two major yield components (large head volume, large seed size) and high levels of resistance to downy mildew and smut. ICRISAT breeders were successful in incorporating downy mildew resistance genes in new cultivars that have allowed this very serious threat to be brought under control in India - at least for the time being (Hash, 1997). 
Breeding for drought resistance received less priority because of the complex nature of the trait and difficulty in assessing the extent of genetic variation for drought resistance, and non-availability of a simple and reliable screening procedure. Another reason was that products arising from a drought-resistance breeding programme at one site were not easily applicable to other drought environments.

In short, in the 1970 s the emphasis was on breeding OPVs. In the 1980 s the emphasis shifted towards hybrid parents. In the 1990s, the focus was on upstream research in addition to the production of restorers and male-sterile lines, including the development of molecular marker-assisted products.

In the 1990 s, ICRISAT made explicit the delineation of six research domains defined in Table 10.3 .

\section{Research Products}

\section{Intermediate products}

ICRISAT has provided parent material to public and private partners since its inception. These include seed parents, i.e. A/B lines as well as pollen parents, i.e. R-lines. A list of varieties/hybrids from ICRISAT parent materials entered into the All India Coordinated Millet Improvement Project (AICMIP) advanced trials is given in Table 10.4.

Table 10.5 lists the quantities of pearl millet breeder seed distributed by ICRISAT to public and private seed multiplication agencies in India during the period 1987-1998. This supply has been substantial, with trends showing an increasing number of requests. Table 10.5 reflects the relatively higher proportion that is supplied to the private sector; for hybrid parents as well as OPVs. Among hybrid parents, $81 \mathrm{~A}$, $81 \mathrm{~B}, 841 \mathrm{~A}, 841 \mathrm{~B}, 843 \mathrm{~A}$ and $843 \mathrm{~B}$ are the most frequently requested, and therefore supplied, to research agencies, both public and private. The small amounts of hybrid parents, $834 \mathrm{~A}$ and $834 \mathrm{~B}$, that were supplied during 1991-1995 were received by the private sector. The volumes of $841 \mathrm{~A}$ and $843 \mathrm{~A}$ supplied in recent years have been increasing, replacing $81 \mathrm{~A}$ and $81 \mathrm{~B}$, which dominated earlier. It is noteworthy that the quantity required remains high, but the responsibility for production and supply of breeder seed of $81 \mathrm{~A}$ and $81 \mathrm{~B}$ was turned over to public sector seed corporations in India in 1995.

Table 10.6 shows the extent of distribution of germplasm lines in southern African countries through the SADC/ICRISAT Sorghum and Millet Improvement Programme (SMIP), coordinated by ICRISAT. About 40,000 pearl millet germplasm lines were distributed to eight southern African countries, notably Zimbabwe, Malawi and Botswana. 


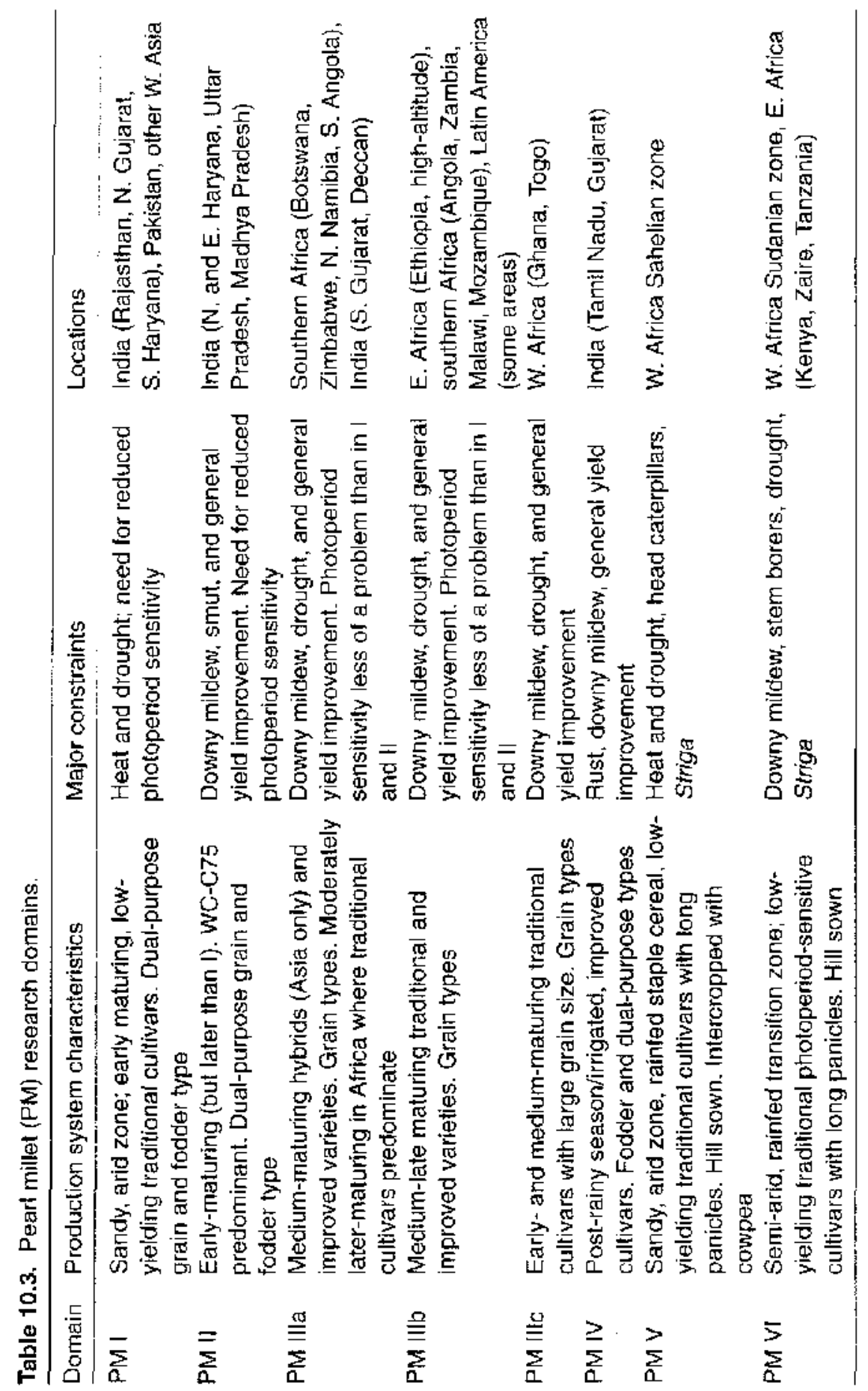


Table 10.4. List of varieties/hybrids entered into the AICMIP advanced trials from ICRISAT parent materials.

\begin{tabular}{|c|c|c|}
\hline $\begin{array}{l}\text { Year of } \\
\text { first entry }\end{array}$ & Varieties & Hybrids \\
\hline $1978 / 79$ & & $\mathrm{ICH} 154,165,105$ \\
\hline $1985 / 86$ & & $\begin{array}{l}\text { ICMH } 423,451,83729,501,83202, \\
82601,83506,83401, \text { IARI } 1, \text { RHRBH } \\
379,372,373,348, \text { HHB 50,56, 59, } \\
\text { AHB } 156,163, \text { PNBH } 4\end{array}$ \\
\hline $1986 / 87$ & & $\begin{array}{l}\text { ICH } 451, \text { HHB } 57,60,61,62,63, \\
\text { ICMH } 8370,84122,84913, \text { RHRBH } \\
8601,8602,8603,8604, \text { GHB 184, } \\
\text { AHB } 212,251,502\end{array}$ \\
\hline $1987 / 88$ & $\begin{array}{l}\text { ICMS } 8010,8283,8253, \\
\text { DPBP } 851, \text { ICMV } 83104, \\
87402,84108,87901, \\
\text { ICMV-F84400, RCB-IC } 861, \\
\text { DPBP-IC } 862, \text { RCB-IC } 861, \\
\text { RCB-IC } 9\end{array}$ & $\begin{array}{l}\text { IARI 1, ICMH } 85109,85231,86217, \\
87004, \text { RHB } 33,34,35,22,24,27, \\
28,30, \text { RHRBI } 8605+B 16,8607, \text { HHB } \\
64,61,68, \text { PNBH } 6, \text { AHB } 615,619, \\
623, \text { GHB } 179,181,205, \text { ICMP } 451\end{array}$ \\
\hline $1988 / 89$ & $\begin{array}{l}\text { ICMV 85328, 86104, } 86120 \\
87902,88907, \text { ICMP } 88130\end{array}$ & $\begin{array}{l}\text { ICMH } 87003,87004,88088,85118, \\
87353,88951, \text { PHB 122. RHRBH 122, } \\
\text { RHRBH } 8701,8702, \text { RHB 50, 54, } 58\end{array}$ \\
\hline $1991 / 92$ & $\begin{array}{l}\text { ICMV } 87111,88402.88908, \\
88904,87107,89410, \text { RCB- } \\
\text { IC } 891,892,901,902,911 \\
\text { ECC } 6\end{array}$ & $\begin{array}{l}\text { PUSA 23, HHB } 67,90,92, \text { ICMH } \\
88735,89998,89024,90952, \text { AHB } \\
838,840,919,1068,1203, \text { GHB } 228 . \\
235.263,314, \text { RHB 57, 85, 86, 87, 89, } \\
90,91,92,93,94, \text { PNBH } 11,14, \text { PHB } \\
133,136, \text { CZH } 859-1\end{array}$ \\
\hline $1992 / 93$ & $\begin{array}{l}\text { CZ-IC 923, 922. 924, GICV } \\
91123,88921,92191, \text { PCB- } \\
\text { IC } 148, \text { RCB-IC 912, } 926 \\
924,925\end{array}$ & $\begin{array}{l}\text { HHB } 88,94,95,96,99,100, \text { CZH } \\
848, \text { PUSA } 350, \text { PHB } 138, \text { RHB } 95, \\
96,97, \text { ICMH } 91205, \text { AHB } 1073, \\
\text { GHB } 274, \text { PNBH } 17, \text { IBH } 5527,5534\end{array}$ \\
\hline $1993 / 94$ & $\begin{array}{l}\text { AIMP 92901, GICKV } 92474 \text {, } \\
91773,92130, \text { CZP-IC-315 }\end{array}$ & $\begin{array}{l}\text { PUSA } 620,613,605,623, \text { PNBH } 18, \\
19,20,22,23,25, \text { RHB 98, 99, 100, } \\
101, \text { PHB } 141, \text { CZH } 921.922, \text { DBDH } \\
1, \text { HHB } 69,105,106,107,108\end{array}$ \\
\hline $1994 / 95$ & $\begin{array}{l}\text { RCB-IC 224, GICKV } 93191, \\
93471,93752,93771, \text { ICMV } \\
93842\end{array}$ & \\
\hline $1996 / 97$ & & ICMH-356, PUSA 322 \\
\hline
\end{tabular}

Source: Bantilan and Deb (2000) prepared from All India Coordinated Millet Improvement Progress Report. 


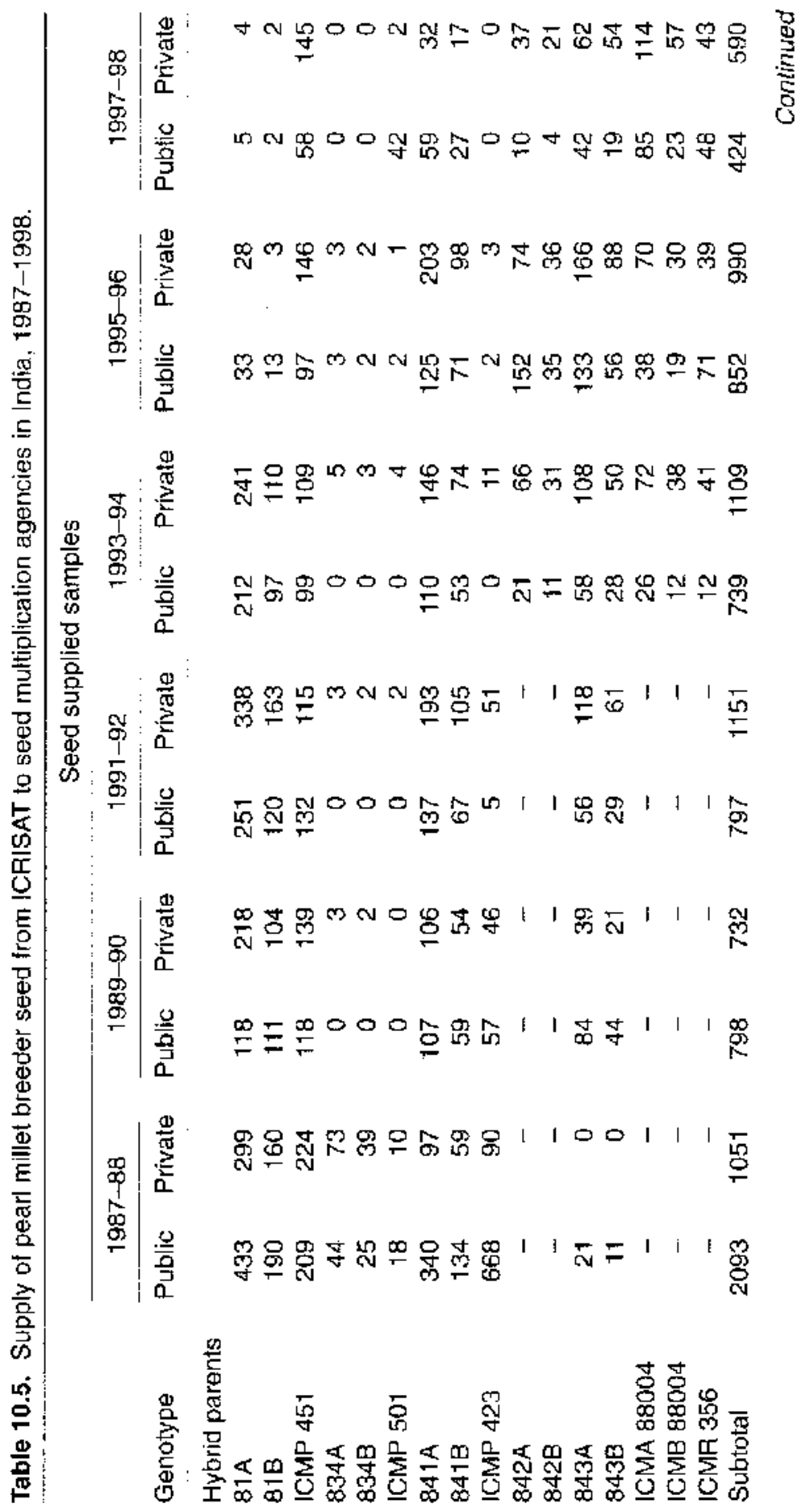




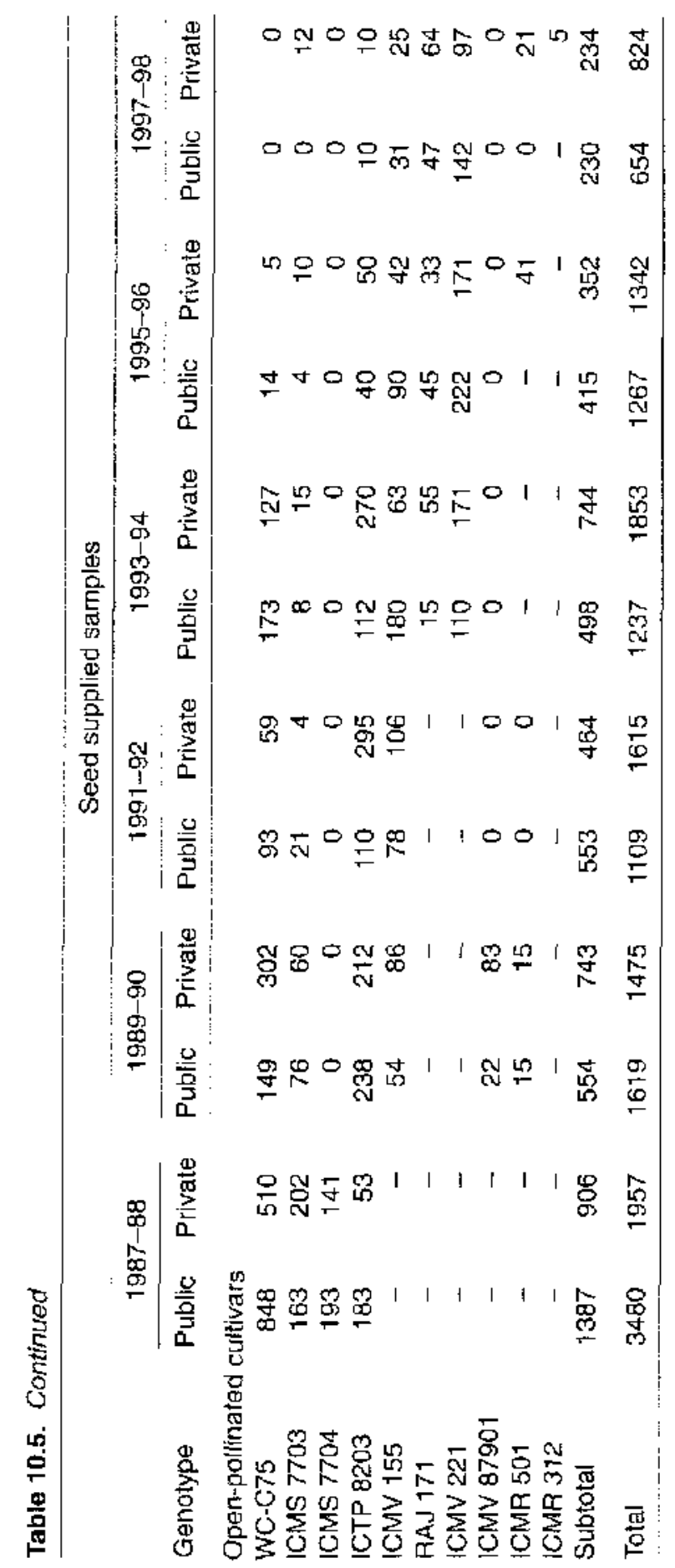


Table 10.6. Number of pearl millet germplasm lines distributed to the SADC countries.

\begin{tabular}{lc}
\hline Country & No. of lines distributed \\
\hline Angola & 97 \\
Botswana & 3,000 \\
Lesotho & - \\
Malawi & 5,000 \\
Mozambique & 200 \\
Namibia & - \\
South Africa & 100 \\
Swaziland & - \\
Tanzania & 6,000 \\
Zambia & 1,200 \\
Zimbabwe & 24,000 \\
Total & 39,597 \\
\hline
\end{tabular}

Source: SMIP (1999).

In addition to the information gathered from breeder seed records, we also surveyed private companies in India under a study jointly undertaken by ICRISAT and Rutgers University to discover the use of ICR1SAT breeding materials by the seed sector in India. Results of the survey are provided in Tables 10.7 and 10.8. Thirty-seven companies involved in pearl millet production responded to the survey questionnaire. Of these 37 companies, 34 are using ICRISAT breeding materials in their programme. About two-thirds use ICRISAT materials directly as hybrid parents, parents in crossing and for selection, One-quarter of the companies are directly producing ICRISAT varieties (Table 10.7). More than half of these companies feel that ICRISAT contributes more than $50 \%$ of their material in their breeding programme (Table 10.8). In terms of the level of importance of breeding materials obtained from

Table 10.7. Use of ICRISAT breeding material in the private sector research programme.

\begin{tabular}{lcc}
\hline Mode of using & $\begin{array}{c}\text { Number of } \\
\text { companies }\end{array}$ & Percentage \\
ICRISAT breeding material & 24 & 71 \\
By selection from ICRISAT material & 22 & 65 \\
As parents in crossing & 20 & 59 \\
Used directly as parents of hybrids & 8 & 24 \\
Used directly as varieties &
\end{tabular}

Note: Total number of companies using ICRISAT breeding material $=34$.

Source: ICRISAT-Rutgers University Study. 
Table 10.8. Contribution of ICRISAT pearl millet breeding material.

\begin{tabular}{lc}
\hline $\begin{array}{l}\text { Percentage contribution } \\
\text { from ICRISAT }\end{array}$ & $\begin{array}{c}\text { Number of } \\
\text { companies }\end{array}$ \\
\hline Directly released from ICRISAT (100\%) & 9 \\
$76-99 \%$ & 4 \\
$51-75 \%$ & 4 \\
$26-50 \%$ & 16 \\
Up to $25 \%$ & 5 \\
No contribution from ICRISAT & 6 \\
Details not provided & 19 \\
\hline
\end{tabular}

Note: Total number of cultivars released/developed/sold by these companies is 63 .

Source: ICRISAT-Rutgers University Study.

different sources, out of 35 companies which responded, 28 mentioned ICRISAT as a very important source while six others mentioned it as one important source.

\section{Varietal production}

ICRISAT has also developed OPVs and hybrids. In 1982., an JCR1SATbred, downy mildew resistant, open-pollinated variety, WC-C75. produced grain and stover yields equal to the best available hybrid at that time (BJ 104) and was released in India. This variety provided a timely alternative to the susceptible BJ 104, and to low-vielding local landraces. The rapid multiplication of VVC-C75 and its adoption by farmers helped to prevent a decline in pearl millet production. In 1986, an ICRISAT downy mildew resistant hybrid, ICMH 451 (also known as MH 179) was released. It outyielded all other varieties and hybrids released earlier, and its seed production was relatively easy and profitable.

Table 10.9 shows the temporal distribution of pearl millet cultivar releases by origin in different countries. The average number of released varieties per annum has increased over time, especially in India. In southern Africa, most releases came only after the SADC/ICRISAT SMIP was launched in 1983 .

Released cultivars, according to their pedigrees, are classified as ICRISAT cross, ICRISAT parent and ICRISAT network (i.e. cultivars developed by national programme or germplasm materials released as superior varieties through ICRISAT network trials), There was no release based on ICRISAT material prior to 1982. Out of 49 releases worldwide in the $1980 \mathrm{~s}, 23$ releases were of ICRISAT origin; out of 59 releases in the 


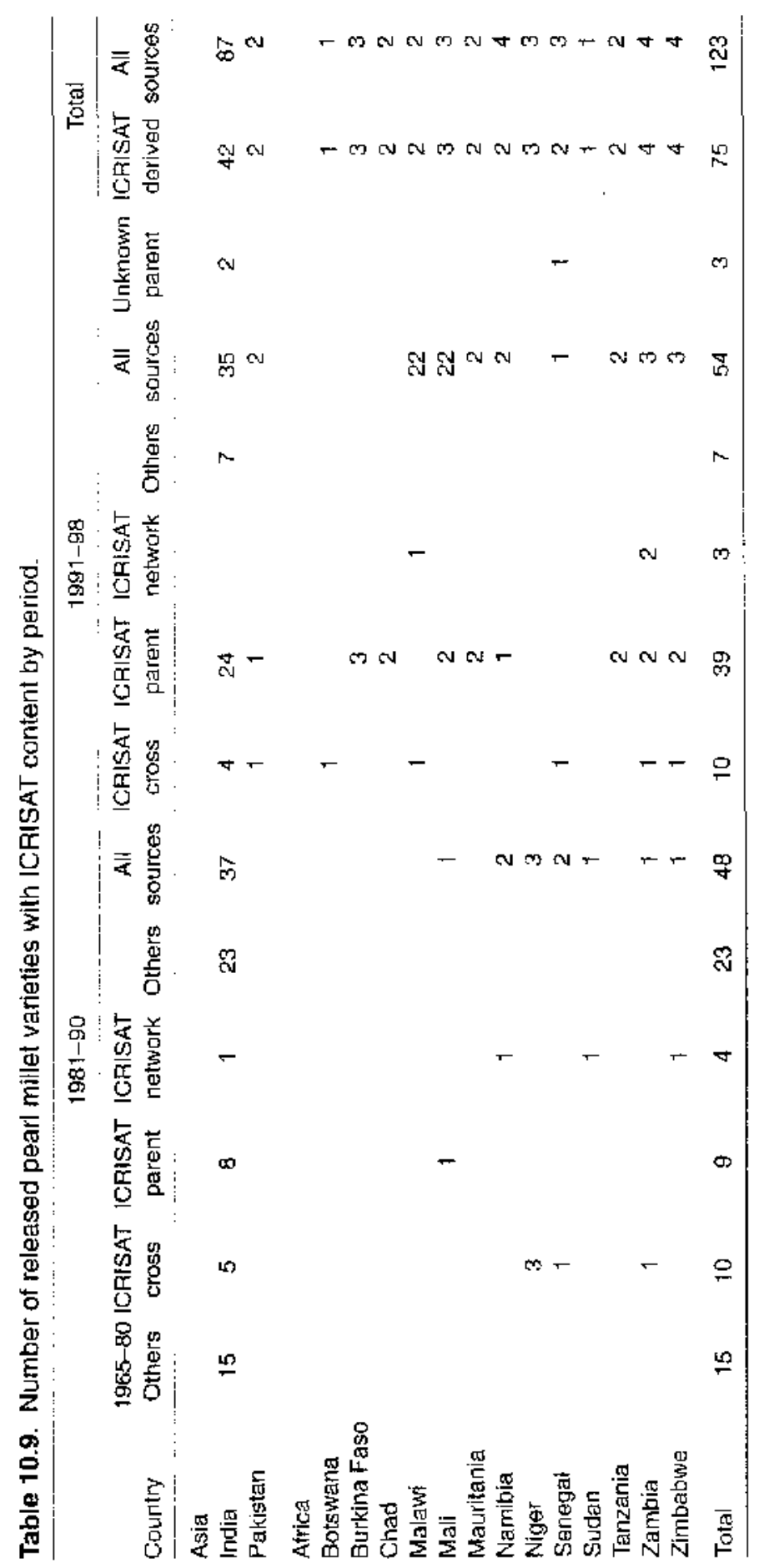


1990s, 52 were of ICRISAT origin. Two points can be noted. First, particularly in Africa, many of the released varieties were developed by ICRISAT. Second, as NARS breeding programmes grew stronger in India, ICRISAT parents (rather than finished material) grew more in importance.

\section{Adoption of Improved Cultivars}

Adoption rates of improved pearl millet cultivars in different countries are provided in Table 10.10. Inter-country comparison of adoption shows that adoption rates vary from $5 \%$ to $65 \%$. In India, the adoption rate is $65 \%$ and in Namibia, it is nearly $50 \%$. Adoption rates are around $20-30 \%$ in Zambia, Mali, Zimbabwe and Botswana.

Figure 10.2 shows adoption trends in different districts of India for the period 1966-1994, based on district-level data obtained from published sources. Adoption of improved pearl millet cultivars has increased significantly over time, starting from very low adoption levels in the late 1960s. In 1992-1994, adoption was over 80\% in most districts in Maharashtra (central India), Gujarat (western India) and Tamil $\mathrm{Nadu}$ (southern India). About 40 districts of India had attained more than $80 \%$ adoption rates. Increasing adoption over time was influenced by the development of downy mildew-resistant varieties at 4- to 5-year intervals. Widespread adoption has led to major yield gains, as discussed later.

Indian farmers were asked to rank the traits they liked in the improved cultivars they are growing. High grain yield ranked first in all states, while high fodder yield ranked second in Maharashtra, Haryana and Gujarat (Table 10.11). Other farmer-preferred traits were short duration, disease (downy mildew) resistance, drought resistance, good taste and large grain size (Bantilan et al., 1999a,b). Tamil Nadu farmers cited 18 different factors that influenced them to adopt improved cultivars, but about $60 \%$ cited high yield, $10 \%$ cited resistance to drought and $9 \%$ cited seed availability (Ramasamy et al., 1999).

Adoption of improved cultivars in three regions in Mali rose from $12 \%$ in 1990 to $23 \%$ in 1995 (Yapi et al., 1998). Across the three study regions in Mali, the main reasons for adoption of new millet varieties are earliness (91\%), productivity (72\%) and food quality (33\%). These reasons vary in order of importance in the three regions, perhaps due to rainfall differences.

About $50 \%$ of the total pearl millet area in Namibia is under one pearl millet variety, Okashana 1, developed by ICRISAT (Rohrbach et al., 1999). Reasons for the high adoption were: (i) strong assistance from an international research centre such as ICRISAT; (ii) close collaboration of researchers with farmers; and (iii) complementary investments in seed production. 


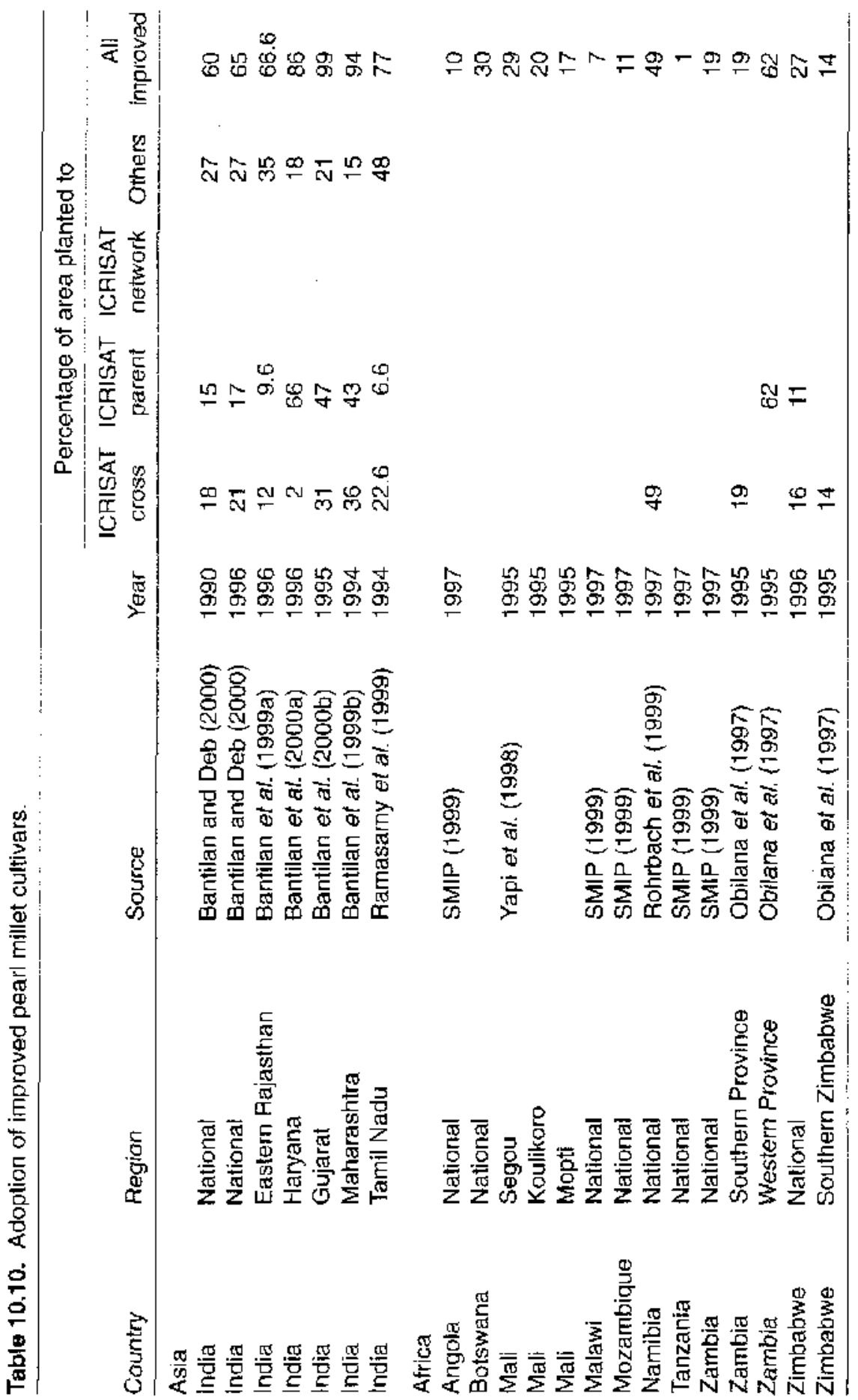




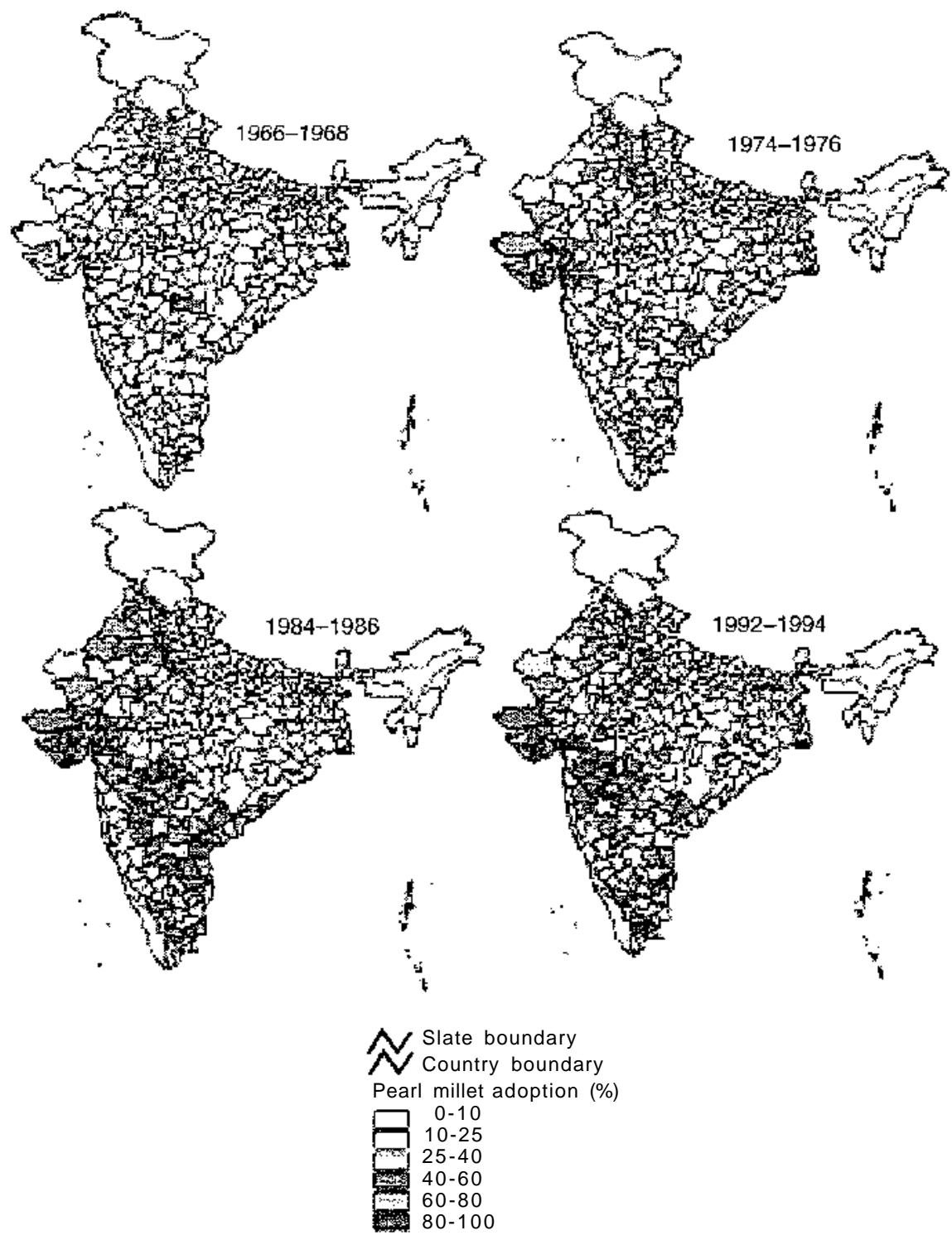

Fig. 10.2. Rate of adoption (\%) of improved pearl millet cultivars in India.

In brief, reasons for high adoption of improved pearl millet cultivars are: high yield, short duration, reduced farmer risk due to early maturity and downy mildew resistance (India), and availability of seeds through private and public seed sector. 
Table 10.11. Traits of improved pearl millet cultivars liked by farmers of selected states of India.

\begin{tabular}{lccccc}
\hline & \multicolumn{5}{c}{ Ranks provided by the farmers of } \\
\cline { 2 - 5 } Traits & $\begin{array}{c}\text { Maharashtra } \\
\text { Reference year }\end{array}$ & Rajasthan & Gujarat & Haryana & Tamil Nadu \\
\hline Grain yield & 1994 & 1996 & 1995 & 1996 & 1994 \\
Fodder yield & 2 & 1 & 1 & 1 & 1 \\
Short duration & 2 & 4 & 2 & 2 & \\
Disease resistance & 3 & 2 & 6 & 3 & 3 \\
Drought resistance & 2 & 5 & 3 & 4 & 2 \\
Better taste & 4 & 3 & 5 & 5 & 4 \\
Bold grain size & 5 & 7 & 4 & & 4 \\
\hline
\end{tabular}

Source: Bantilan et al. (1999a,b, 2000a,b) and Ramasamy et al. (1999).

\section{Constraints to adoption as reported by farmers}

Indian farmers were asked to cite and rank the constraints they face in adopting improved pearl millet cultivars. The major constraints were non-availability of seed, low fodder yield of existing cultivars, lack of awareness, high water requirement for improved cultivars, poor extension service, and poor grain and fodder quality (Bantilan et al., $1999 a, b)$.

The most significant constraints to adoption cited by Mali farmers are lack of information about the existence of new varieties (49\%). lack of seed (33\%) and poor soil (26\%) (Yapi et al., 1998). Lack of information and seed are the most important constraints in all three regions, while poor soil is only a problem in Mopti. In Segou, there is a strong preference for local varieties. The need for fertilizer is the most important constraint in Koulikoro.

\section{Dimensions of Impacts}

\section{Improvement in efficiency in NARS research}

As already noted, progress in the release of new varieties has increased significantly as a result of ICRISAT support to NARS. Use of ICRISATdeveloped material that can be tested by NARS has reduced research lags - for example, the variety Okashana 1. earlier developed and tested by ICRISAT in India, underwent only 3 years of adaptive testing before being released in Namibia, thus greatly reducing the time and expense 
of developing a new variety from scratch. Another major factor in improving NARS research efficiency has been large-scale training and capacity building efforts by ICRISAT. For example, in southern Africa, which lacked trained research staff, over 650 scientists and technicians have undergone training programmes or received scholarships for higher education.

\section{Impacts on yield}

District-level yields data for 1992-1994 and 1966-1968 from 238 districts in India were compared in order to estimate the impacts on yield. Yield has increased in almost all the districts. For example, in the late 1960 s, most districts of Maharashtra and Gujarat recorded yields less than 500 $\mathrm{kg} \mathrm{ha}^{-1}$ and slightly higher than $500 \mathrm{~kg}$ in Tamil $\mathrm{Nadu}$ and Haryana. However, in the $1990 \mathrm{~s}$, this had increased by $500-1000 \mathrm{~kg} \mathrm{ha}^{-1}$ in Gujarat, Maharashtra and Haryana (Table 10.12). Yield increases have been particularly large in some districts where adoption levels are high.

Results of farm surveys show that in all Indian states, improved cultivars give higher grain and fodder yields than local varieties. The percentage increase is higher for grain yield than for fodder yield.

Adoption of new millet varieties in Mali increased pearl millet yields from $570 \mathrm{~kg} \mathrm{ha}^{-1}$ with the best local variety to $930 \mathrm{~kg} \mathrm{ha}^{-1}$ for improved varieties (Yapi et al., 1998). These yields are consistent with those found in previous studies. Shetty et al. (1991) noted that, in Mali millet, yields vary from $300 \mathrm{~kg} \mathrm{ha}^{-1}$ in the Sahelian zone to $700 \mathrm{~kg} \mathrm{ha}^{-1}$ in the zone with most rainfall in the south, compared with on-station yields of 1500-2000 kg ha-1. On-farm yield estimates by Yapi et al. (1998) seem consistent with these data. With production at these levels, farmers are able to feed their families and have surplus grain to market. Growing improved varieties assures food security and reduces production risks linked to late season drought (Yapi et al., 1998).

Table 10.12. Impact of improved pearl millet cultivars on pearl millet yield in different states of India, 1971-1994.

\begin{tabular}{|c|c|c|c|c|c|}
\hline \multirow[b]{2}{*}{ State } & \multicolumn{3}{|c|}{ Average yield level $\left(\mathrm{kg} \mathrm{ha}^{-1}\right)$} & \multicolumn{2}{|c|}{$\begin{array}{c}\text { Yield gain }(\%) \\
\text { compared to } 1971-74\end{array}$} \\
\hline & $1972-74$ & $1981-83$ & $1992-94$ & $1981-83$ & $1992-94$ \\
\hline Gujarat & 641 & 1380 & 1534 & 115 & 139 \\
\hline Haryana & 578 & 725 & 1309 & 25 & 126 \\
\hline Rajasthan & 265 & 373 & 557 & 41 & 110 \\
\hline
\end{tabular}

Source: Deb et al. (2000). 


\section{Impacts on cost of production and farm profit}

Results from cost of cultivation data showed that the average cost of pearl millet production per tonne, in 1992-1994 compared with 1972-1974, has declined by $35 \%, 42 \%$ and 59\% in Gujarat, Haryana and Rajasthan in India, respectively (Table 10.13). Farm-level surveys in India showed that improved cultivars have more than $40 \%$ lower costs of production estimated on a full-cost basis (Table 10.14).

Yapi etal., (1998) reported that improved varieties reduced production costs in Mali by $38 \%$ (US\$38 $\mathrm{t}^{-1}$ ). compared with local millet varieties. The absolute production cost per hectare was higher for improved varieties because of additional inputs, but the higher productivity still provided economies. Improved cultivars have increased farm profit in Mali by $63 \%$. The net income of Indian farmers, computed on a variable cost basis, increased by up to five times (Table 10.14).

\section{Returns on research}

Several studies have estimated the returns from pearl millet research in Mali. Namibia and Zimbabwe. Considering research and extension costs, the net present value of benefits from research on improved varieties of millet in Mali was estimated at US\$25 million, representing an internal rate of return (IRR) of $50 \%$ (Yapi et al., 1998). Internal rates of return for pearl millet research in Zimbabwe from SDMV 89004 were estimated at $44 \%$. Farm-level studies in Namibia showed that the internal rate of return to pearl millet research was $50 \%$, with a net present value (NPV) of this research of more than US\$10 million in 1998 (Rohrbach et al., 1999).

\section{Spillover impacts}

An important objective of international agricultural research institutions is to determine the extent to which research undertaken at one location

Table 10.13. Impact of improved pearl millet cultivars on cost of production of pearl millet in India, 1971-1995.

\begin{tabular}{lcccccc}
\hline & & & & \multicolumn{2}{c}{$\begin{array}{c}\text { Cost reduction (\%) } \\
\text { compared to }\end{array}$} & $1972-74$ \\
\cline { 2 - 4 } State & $1972-74$ & $1981-83$ & $1992-94$ & & $1981-83$ & $1992-94$ \\
\cline { 2 - 4 } Gujarat & 3814 & 2665 & 2464 & 30 & 35 \\
Haryana & 4277 & 2881 & 2488 & 33 & 42 \\
Rajasthan & 3898 & 1676 & 1593 & 57 & 59 \\
\hline
\end{tabular}




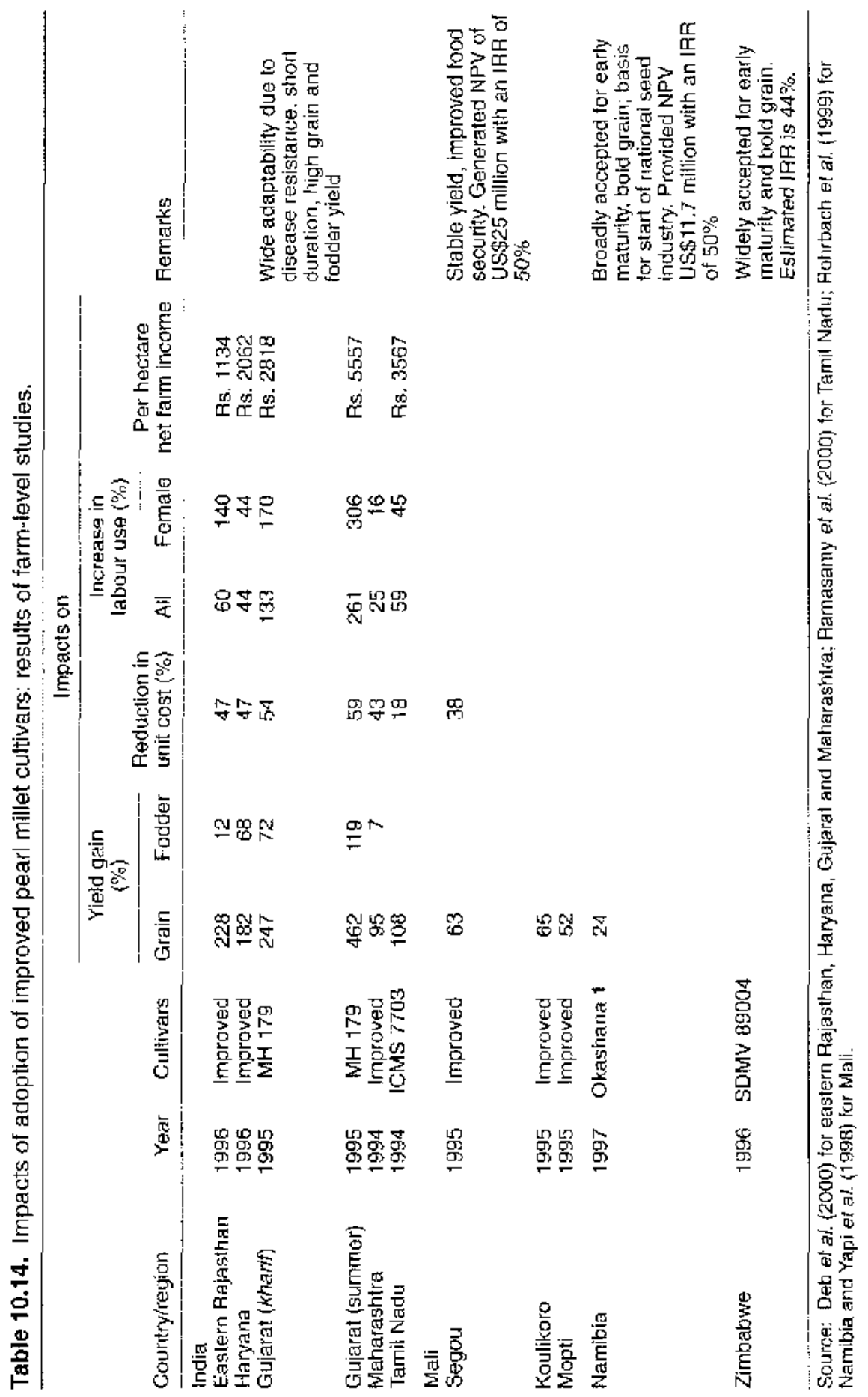


may impact on other regions of interest. ICRISAT has, as a policy, distributed a wide range of parental materials to breeding programmes in the NARS and private seed industries throughout the semi-arid tropics. This has contributed to enhanced technology spillover. For example, ICMV 221, Okashana 1 and WC-C75 were originally bred for India, but ICMV 221 was also released in Kenya and Uganda.

An open-pollinated variety (ICTP 8203), developed at ICRISATIndia from Togo populations; was introduced to Namibian farmers through the SADC/ICRISAT Sorghum and Millet Improvement Programme (SMIP) and the efforts of the Rossing Foundation during $1986 / 87$ and $1987 / 88$ along with a total of 50 varieties on demonstration trial. Farmers liked this variety when they saw it in the demonstration field. In 1989, the Rossing Foundation distributed large quantities of seed of ICTP 8203 under the name of Okashana 1. Okashana 1 now occupies about $50 \%$ of the pearl millet area in Namibia (Rohrbach et al., 1999). Okashana 1 (ICMV 88908) was released in Malawi, Namibia and Botswana. In Zimbabwe, private seed companies produce and market Okashana 1, though it is yet to be formally released.

Similarly, WC-C75 was released in Zambia. Kaufela was developed for Zambia but also released in Botswana, Tanzania and Mozambique. Okoa and Shibe were originally selected for Zimbabwe but Okoa was also released in Botswana and Shibe in Tanzania (ICRISAT, 1996, p. 30; Monyo, 1998). These indicate that the genetic material used in the development of these cultivars has wide adaptation, suggesting that there are important spillovers from ICRISAT genetic enhancement research in pearl millet.

\section{Conclusions}

This chapter documents the benefits generated from genetic enhancement research in pearl millet in sub-Saharan Africa and Asia. The pearl millet breeding programme at ICRISAT, in partnership with NARS, has released 75 new varieties and hybrids during 1981-1998. ICRISAT had also developed hybrid parents and supplied materials to its public-and private-sector partners throughout India and Africa. During 1981-1998, all released cultivars in the study countries (except India) were ICRISAT-derived (either ICRISAT bred, or developed from ICRISAT parents or obtained through ICRISAT networks). The increased dominance of ICRISAT parent-material-based releases indicates the importance of ICRISAT's role in the development of parent materials and other intermediate breeding products. The availability of high quality ICRISATdeveloped parental materials and their use by private and public sector pearl millet breeders have substantially shortened the research and 
development time and resulted in increased efficiency of NARS breeding programmes. Among the improved cultivars adopted in farmers' fields, a significant proportion are ICRISAT-bred or based on ICRISAT materials. Adoption of private-sector cultivars with ICRISAT parentage is also increasing.

ICRISAT research has helped to increase yield, reduce production costs, and improve the efficiency of breeding programmes throughout the world. Countries with less well-endowed research facilities, especially in Africa, have benefited most from ICRISAT-bred cultivars and through research spillovers.

\section{Acknowledgements}

The authors are grateful to Drs K.N. Rai, K. Anand Kumar, C.T. Hash, E.S. Monyo, Paula Bramel, N. Kameswara Rao, David Rohrbach, H.A. Freeman, John Brennan and Jeff Davis for their useful comments and insightful interactions during early versions of this chapter; Ajay Vadrachary is thanked for editorial assistance; and Dr F.T. Bantilan, Irshad Ahmed and Md. Moinuddin for GIS-based mapping and delineation of pearl millet domains. However, the views expressed in this chapter are those of the authors.

\section{References}

Anand Kumar, K. (1993) Pearl millet in Western Africa. In: Byth. D.E. (ed.) Sorghum and Millets: Commodity and Research Environments. International Crops Research Institute for the Semi-Arid Tropics (ICRISAT), Patancheru, India.

Bantilan, M.C.S. and Deb. U.K. (2000) Joint impacts of partnership of ICRISAT-NARS pearl millet genetic improvement. Paper presented at the American Association for Advancement of Science (AAAS) conference held at Washington, DC, USA.

Bantilan. M.C.S., Chopde, V.K., Gupta, S. and Deb, U.K. (1999a) Factors influencing adoption of improved pearl millet cultivars in Rajasthan, India. Poster paper presented at the workshop on Summer Training in Socio-economics and Policy Research on 27 July 1999 at the ICRISAT.

Bantilan. M.C.S., Rao. Y.M., Gujral, H.K. and Deb, U.K. (1999b) Critical factors influencing adoption of improved pearl millet cultivars in Maharashtra, India. Poster paper presented at the workshop on Summer Training in Socio-economics and Policy Research of ICRISAT, 27 July 1999 at the ICRISAT.

Bantilan, M.C.S., Deb, U.K., Gupta. S. and Chopde, V.K. (2000a) Improved pearl millet cultivars in Haryana: adoption and impacts. Unpublished manuscript.

Bantilan, M.C.S., Deb, U.K. and Rao, Y.M. (2000b) Improved pearl millet 
cultivars in Gujarat: adoption and impacts. Unpublished manuscript.

Dave, H.R. (1987) Pearl millet hybrids. In: Proceedings of the International Pear! Millet Workshop, 7-11 April 1986. ICRISAT, India, Patancheru, India, pp, 121-126.

Deb, U.K., Bantilan, M.C.S. and Rai, K.N. (2000) Impacts of improved pearl millet cultivars in India. Paper presented at the workshop on impacts of Agricultural Research in India, 10-11 February, ICRISAT, Patancheru, India.

Dendy, D.A.V. (1995) Sorghum and millets: production and importance. In: Dandey, D.A.V. (ed.) Sorghum and Millets: Chemistry and Technology. American Association of Cereal Chemists, St Paul, Minnesota, pp. 11-26.

FAO (1998) FAO Statistical Data Base 1998.

Harinarayana, G., Anand Kumar. K. and Andrews, D.J. (1999) Pearl millet in global agriculture. In: Khairlwal, I.S., Rai, K.N., Andrews, D.J. and Harinarayana, G. (eds) Pearl Millet Breeding. Oxford \& IBH Publishing, New Delhi, pp. 480-506.

Hash, C.T. (1997) Research on downy mildew of pearl millet. In: Bantilan, M.C.S. and Joshi, P.K. (eds) Integrating Research Evaluation Efforts. ICRISAT, Patancheru, India, pp. 121-128.

ICRISAT (1996) Southern and Eastern Africa Highlights. 1996. ICRISAT, Patancheru, India, p. 30.

ICRISAT/FAO (1996) The World Sorghum and Millet Economies: Facts. Trends and Outlook. Joint publication by ICRISAT, India and the FAO, Rome.

Kelly, T.G. and Parthasarathy Rao, P. (1993) Sorghum and millet in Asia. In: Byth, D.E. (ed.) Sorghum and Millets - Commodity and Research
Environment. ICRISAT, Patancheru, India, pp. 93-117.

Monyo, E.S. (1998) 15 years of pearl millet improvement in the SADC region. International Sorghum and Millets Newsletter 39, 17-33.

Nene, Y.L. and Singh, S.D. (1976) Downy mildew and ergot of pearl millet. PANS 22, 366-385.

Obilana, A.B., Monyo, E.S. and Gupta, S.C. (1997) Impact of genetic improvement in sorghum and pearl millet: developing country experiences. In: Proceedings of the International Conference on Genetic Improvement of Sorghum and Pearl Millet, 22-27 September 1996, Lubbock, Texas. INTSORMIL/ ICRISAT Publication No. 97-5, pp. $119-141$.

Rai, K.N. and Hash, C.T. (1994) Genetic enhancement of pearl millet at ICRISAT. In: Bantilan, M.C.S. and Joshi, P.K. (eds) Evaluating ICRISAT Research Impact. ICRISAT, Patancheru, India, pp. 19-25.

Rai, K.N. and Singh, N.B. (1987) Breeding pearl millet male-sterile lines. In: Proceedings of the International Pearl Millet Workshop, 7-11 April 1986. ICRISAT, Patancheru, India, pp. 127-137.

Ramasamy, C., Bantilan, M.C.S., Elongovan, S. and Asokan, M. (1999) Perceptions and adoption decisions of farmers in cultivation of improved pearl millet cultivars a study in Tamil $\mathrm{Nadu}$. Indian Journal of Agricultural Economics 54 (2), 139-154.

Ramasamy, C., Bantilan, M.C.S., Elongovan, S. and Asokan, M. (2000) Improved Pearl Millet Cultivars in Tamil Nadu: Adoption. Impact, and Returns to Research Investment. Impact Series No. 7. ICRISAT, Patancheru, India. 
Rohrbach, D.D., Lechner. W.R., Ipinge, S.A. and Monyo, E.S. (1999) Impact from Investment in Crop Breeding: the Case of Okashana 1 in Namibia. Impact Series No. 4. ICRISAT, Patancheru, India.

Shetty, H.S. (1987) Biology and epidemiology of downy mildew of pearl millet. In: Proceedings of the International Pearl Millet Workshop, 7-11 April 1986. ICRISAT, Patancheru, India, pp. 147-160.

Shetty, S.V.R., Beninati, N.F. and Beckerman (1991) Strengthening Sorghum and Pearl Millet Research in Mali. ICRISAT, Patancheru, India.

Singh, S.D., Bali, S.L. and Thakur, D.P. (1987) Problems and strategies in the control of downy mildew. In: Proceedings of the International Pearl Millet
Workshop. 7-11 April 1986,

ICRISAT, India, pp. 161-172.

Singh, S.D., King, S.B. and Werder, J. (1993J Downy Mildew Disease of Pearl Millet. Information Bulletin No. 37, ICRISAT, Patancheru, India. SMIP (1999) Collaboration and Achievements in Southern Africa, 1983-1999. Matopos Research Station. Bulawayo, Zimbabwe.

Yapi, A., Kergna, A.O., Debrah, S.K.. Sidibe, A. and Sanogo, O. (1998) Impact of sorghum and millet research in Mali. In: Bantilan, M.C.S. and Joshi, P.K. feds) Assessing Joint Research Impacts: Proceedings of an International Workshop on Joint Impact Assessment of NARS/ICRISAT Technologies for the Semi-Arid Tropics, $\quad 2-4 \quad$ December 1996. ICRISAT, Patancheru, India, pp. 76-93. 